\title{
Detection of Yersinia enterocolitica in the Shami goat's milk in the North Sinai Governorate
}

\author{
Y. M. Kamel, A. L. El-Naggar, H. M. El-Shaer \\ Animal and Poultry Production Division, Desert Research Center, El-Mataria, Cairo, Egypt
}

\begin{abstract}
Considerable difficulties are associated with the isolation of Yersinia enterocolitica from food particularly milk and milk products. Most methods are time consuming require enrichment steps and are unable to differentiate pathogenic isolates from non pathogenic ones. The purpose of this study was to evaluate the detection of Yersinia enterocolitica in milk by both polymerase chain reaction (PCR) and conventional culturing methods. Fifty milk samples were collected from Shami goats in North Sinai governorate.

Two primers (DG26 and DG63) were used in PCR and the size of the PCR-product was 440bp. The results obtained by PCR technique were in good agreement with that obtained by conventional culturing method. Five samples $(10 \%)$ were positive by PCR while 4 samples were positive by conventional culturing method. Interestingly, PCR results are obtained within few hours. Moreover, it solved the problem of interpretation of classical biochemical and serological typing in one step without necessity of using additional examinations. This makes diagnosis in food control laboratories much faster and more efficient.
\end{abstract}

Yersinia species are one of the important etiologic microorganisms of food poisoning. Yersinia has a particular importance for the study of consumers, because of its capability for growing in raw milk and remains viable for long periods of time at refrigeration temperatures. Furthermore, law temperature conditions may enhance the growth rate of this potential pathogen relative to the growth of spoilage microorganisms (Ursing et al, 1980).

Although $Y$. enterocolitica is an ubiquitous microorganism, the majority of isolates recovered from foods are non-pathogenic, and thus, it is important to determine the pathogenic significance of isolates (Kapperud, 1991 and De Boer et al., 1986). This can be done with several phenotypic tests, but these are time-consuming and not always reliable (Kwaga et al., 1992). PCR assay has been used to verify the pathogenic strains of $Y$. enterocolitica isolates rapidly and with high specificity (Kapperud et al., 1990; Wren and Tabaqchali, 1990 and Bhaduri et al., 1997). This method is based on specific segments of the virulence plasmid that have known virulence functions such as yadA gene. The virulence plasmid is essential for $Y$. enterocolitica to survive and multiply in lymphoid tissues (Cornelis et al., 1998). The yadA gene codes the major outer membrane protein YadA (Lachica and Zink, 1984 and Skurnik and Wolf-Watz, 1989), which forms a fibrillar matrix on the surface of $Y$. enterocolitica (Kapperud et al., 1987) and is only expressed at $37^{\circ} \mathrm{C}$ (Portnoy and Martinez 1985). YadA plays a protective role in $Y$. enterocolitica, with several different functions (Table 1). The PCR procedure is a rapid in vitro enzymatic amplification of the copy numbers of target DNA sequence (Mullis et al., 1994). The development of these rapid and sensitive PCR techniques increases the sensitivity

Table (1): Role of YadA protein in the virulence of Yersinia enterocolitica.

\begin{tabular}{ll}
\hline \multicolumn{1}{c}{ Function of YadA protein } \\
\hline Serum resistance & Heesemann et al., 1983 \\
Surface hydrophobicity & Lachica and Zink, 1984 \\
Autoagglutination & Skurnik et al. 1984 \\
Adhesion to epithelial cells & Heesemann and Gruter 1987 \\
Expression of fibrils on the surface & Kapperud et al., 1987 \\
Haemagglutination & Kapperud et al., 1987 \\
Binding to intestinal brush border membranes & Paerregaard et al., 1991 \\
Resistance to killing by polymorphonuclear leukocytes & Ruckdeschel et al., 1996 \\
\hline
\end{tabular}


Table (2): Primers used in the PCR technique.

\begin{tabular}{cclcc}
\hline Primers & \multicolumn{1}{c}{ Sequence (5'-3') } & Polarities & $\begin{array}{c}\text { Product } \\
\text { length }\end{array}$ & Gene bank accession number \\
\hline DG62 & TAG TGT TGC CAG AAC AAC TT & Sense & 440 & AF056092 \\
DG63 & CAT TGT ACA TGA CAT CCG AG & Anti-sense & & AF056092 \\
\hline
\end{tabular}

for detection of a DNA sequence that may be present in trace amounts in foods (Bej et al., 1994, Millar et al., 1996, and Trkov et al., 1999). In this study, the PCR procedure using yadA gene was a trial for the direct detection of Yersinia enterocolitica in Shami Goats milk in comparison with the conventional methods.

\section{Material and Methods}

Bacterial strain. Yersinia enterocolitica ATCC 23715 was grown at $25^{\circ} \mathrm{C}$ in tryptic soya broth containing $0.6 \%$ yeast extract (TSBY).

Primer design. The DNA primers used in the present study were synthesized in Bio-System and are listed in table (2). The yadA gene was chosen, as it is virulence determinant in Yersinia enterocolitica and has been tested in food (beef and pork) for the specific detection of Yersinia enterocolotica (Kapperud et al., 1993).

Collection of raw milk samples. Goat milk samples were collected from different locations representing the extensive system in North Sinai governorate (El-Arish, El-Sheikh Zoid, Rafah, Al-Qosima and Nekhle). Fifty milk samples were collected under complete aseptic condition where udder halves were cleaned and disinfected prior to sampling. The first three squirts of milk were discarded from each teat and samples were collected into $250 \mathrm{ml}$ sterile bottles and transmitted to the laboratory for bacteriological examination and DNA extraction.

Bacteriological examination. Five $\mathrm{ml}$ of milk samples were transferred aseptically to $45 \mathrm{mls}$ of sterile phosphate buffered saline (PBS), mixed well and incubated to $22-25^{\circ} \mathrm{C}$ for 24 hours, then $0.5 \mathrm{ml}$ of the sterile PBS that treated with alkali by transferring it into $4.5 \mathrm{ml}$ of $0.5 \% \mathrm{KOH}-0.5$ $\% \mathrm{NaCl}$. After mixing for 3-4 seconds, loopfuls of this broth (Alulisio et al., 1980) were streaked onto MacConky (oxoid) with $5 \mathrm{~g} / \mathrm{L}$ of tween 80 (Lee, 1977), and on cefsuladin Irgasan Novobiocin (CIN) agar (Biolife) and then were incubated at $30{ }^{\circ} \mathrm{C}$ for 2 days (Schiemann and Wauters, 1992). Five to six colonies showing
Yersinia characteristics (dark red "bulls eye" surrounded by a transparent border) were picked up and streaked onto nutrient agar slant which were incubated at $25^{\circ} \mathrm{C}$ for 24 hours. Colonies were tested for catalase, Gram staining, motility at $25^{\circ} \mathrm{C}$ and $37^{\circ} \mathrm{C}$, growth on triple sugar iron agar (TSI), urea broth and lysine decarboxylase. Pure cultures that were urea positive, producing acid in triple sugar iron agar, and negative for gas production, $\mathrm{H}_{2} \mathrm{~S}$, lysine decarboxylase and motility at $25^{\circ} \mathrm{C}$ were considered Yersinia enterocolitica.

DNA extraction from milk. Each milk sample $(10 \mathrm{ml})$ was pretreated with one $\mathrm{ml}$ of $25 \%$ sodium citrate. The DNA was extracted using a modification of the method described previously by Drake et al., 1996. Briefly, petroleum ether $(2 \mathrm{ml}), \quad 100 \%$ ethanol $(2 \mathrm{ml})$ and saturated ammonium hydroxide $(4 \mathrm{ml})$ were added, mixed, and the solution was centrifuged at $8000 \mathrm{~g}$ for 10 min at room temperature. The supernatant was discarded and the pellet was resuspended in 500$900 \mu \mathrm{l}$ STET buffer $(80 \%$ sucrose, $0.5 \%$ Triton$\mathrm{X}-100,50 \mathrm{mmol}$ EDTA, $50 \mathrm{mmol}$ Tris- $\mathrm{HCl}$ at $\mathrm{pH}$ 8.0) and transferred to a $2 \mathrm{ml}$ microcentrifuged tube. The tube was vortexed occasionally for $10 \mathrm{~min}$. An equal volume of phenol, chloroform and isoamyl alcohol was added, mixed, and the tube centrifuged at $17000 \mathrm{~g}$ for $10 \mathrm{~min}$ at room temperature. The supernatant fluid was transferred to a new tube and an equal volume of chloroform was added, mixed, and centrifuged as mentioned above. The clear aqueous phase was transferred to a new tube and the DNA was precipitated with 0.1 volume 3 molar sodium acetate, $\mathrm{pH} 5.4$, one volume cold isopropanol and $30 \mu \mathrm{g}$ glycogen. The sample was centrifuged at $12000 \mathrm{~g}$. for $30 \mathrm{~min}$. at room temperature to pellet the DNA. The air-dried pellet was resuspended in $15 \mu \mathrm{l}$ nuclease-free water and the DNA concentration was measured at $260 \mathrm{~nm}$ using UV spectrophotometer.

PCR design and amplification conditions. 
Table (3): Comparison between PCR reaction and traditional methods for Yersinia enterocolitica detection in raw milk samples

\begin{tabular}{ccccccccc}
\hline \multirow{2}{*}{ Total samples } & \multicolumn{3}{c}{ PCR } & \multicolumn{3}{c}{ Traditional culture } \\
\cline { 2 - 9 } & $+\mathrm{Ve}$ & $\%$ & $-\mathrm{Ve}$ & $\%$ & $+\mathrm{Ve}$ & $\%$ & $-\mathrm{Ve}$ & $\%$ \\
\hline 50 & 5 & 10 & 45 & 90 & 4 & 8 & 46 & 92 \\
\hline
\end{tabular}

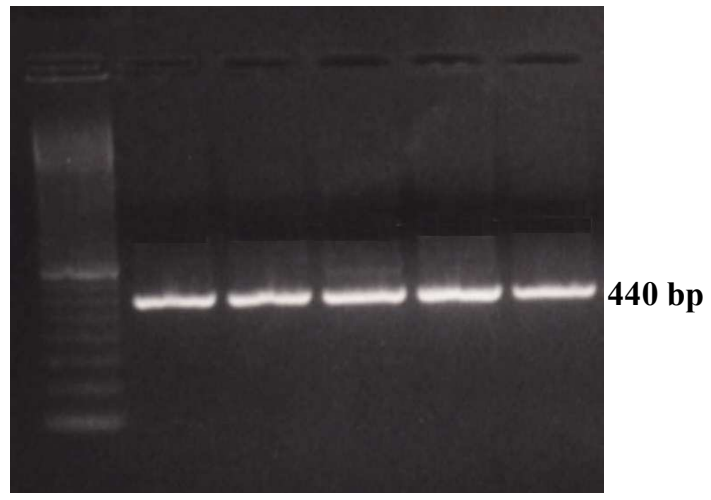

Fig. (1): Detection of Yersinia enterocolitica in raw milk samples by PCR from milk samples using DG62 and DG63 primers. Lane1 shows DNA Ladder. Lane2 control positive sample for Yersinia enterocolitica; lanes 3, 4, 5 \& 6 are Positive samples.

DG62 and DG63 primers were used for amplification of fragment length of 440bp. The amplification of the extracted DNA from both milk samples and that of the reference strain of Yersinia enterocolitica was achieved on thermocycler Perkin-Elmer as follows. Each 50ul of PCR reaction mixture contained $10 \mathrm{mM}$ Tris$\mathrm{HCl}(\mathrm{pH} 8.3), 50 \mathrm{mM} \mathrm{KCl}, 1.5 \mathrm{mM} \mathrm{MgCl} 2$, 200uM dNTPS, 2.5 united of Taq DNA polymerase, $100 \mathrm{Pmol}$ of each primer and varying amounts of template DNA.

Samples were denatured at $94^{\circ} \mathrm{C}$ for $5 \mathrm{~min}$ and subjected to amplification cycles in the thermocycler. Each PCR cycle consisted of a 45 seconds denaturation step $\left(94^{\circ} \mathrm{C}\right)$, a 45 seconds annealing step $\left(55^{\circ} \mathrm{C}\right)$, and a 45 seconds extension step $\left(72^{\circ} \mathrm{C}\right)$. Finally, products were extended for 7 minutes at $72^{\circ} \mathrm{C}$. At the completion of amplification cycles, PCR products were analyzed by $1.5 \%$ agarose gel electrophoresis and stained with ethidium bromide.

\section{Result and Discussion}

Milk captured a great importance in the Bedouin life because it is one of the cheapest sources of protein and considered one of animal protein sources in their diet. On the other hand, milk may be microbiologically contaminated by multiple bacterial species of major public health significance especially in low hygienic areas; one of them is Yersinia enterocolitica.

Since the primers DG62 and DG63 were designed for selective detection of the sequences within the yadA gene of Yesinia enterocolitica after checking with the GenBank Blast program, it was expected to be specific and not to amplify other food poisoning bacteria. The total DNA was extracted from Yersinia enterocolitica and was subjected to the PCR with DG62/DG63 primers. As expected, DG62/DG63 specifically amplified $440 \mathrm{bp}$ fragment, as shown in fig. 1.

As shown in Table 3, the result obtained from PCR method to large extent was in agreement with the traditional method of culture. The little difference between the results may be attributed to the presence of too few numbers of this pathogen cells to grow or a pathogen was dead and failed to grow on the culture media. Moreover, for direct detection by PCR, the whole procedure work took only five hours to identify Yersinia enterocolitica in milk. In contrast, the conventional method usually requires enrichment in liquid media, isolation of pure cultures on selective differential plating method and identification of isolates by biochemical and serological tests that take 1-2 weeks to be completed (Swaminathan et al., 1982). Therefore, PCR-based method provides more convenient and faster way than the conventional method to detect Yersinia enterocolitica in milk.

The finding of a pathogen like Yersinia enterocolitica in milk supports the well known need for greater care regarding health hazard critical control point associated with production and handling of milk. There is also an urgent need to develop methods that will decrease the incidence of contamination, especially in ready to consume product as milk. Furthermore, adequate 
heating must be ensured, and all personnel involved in milking, distribution, storage, handling should be aware of the potential risks of cross contamination.

\section{Acknowledgment}

This research was supported under Grant No., M18-001, Middle East Regional Cooperation (MERC) program, Bureau for Economic Growth, Agriculture and Trade, U. S. Agency for International Development.

\section{References}

Alulisio, C.C.G.; Mehlman, I. J. and Sanders, A.C. (1980): Alkali method for rapid recovery of Yersinia enterocolitica and Yersinia pseudotuberculosis from foods. Appl. Environ. Microbiol., 39:135-140.

Bej, A.K.; Mahhubani, M.H.; Boyce, M.J. and Atlas, R.M. (1994): Detection of Salmonella spp. In oysters by PCR. Appl. Environ. Microbiol., 60: 368-373.

Bhaduri, S.; Cottrell, B. and Pickard, A. R. (1997): Use of single procedure for selective contribution of Yersinia enterocolitica virulence factors to evasion of microbicidal action of neutrophils. Infect. Immun., 64: 724-733.

Cornelis , G. R.; Boland, A.; Boyd, A. P.; Geuijen, C.; Iriarte, M.; Neyt, C.; Sory, M. P. and Stainier, I. (1998): The virulence plasmid of Yersinia, an anti-host genome. Microbiol. Mol. Biol. Rev., 62: 1315-1352.

De Boer, E.; Seldam, W. M. and Oosterom, J. (1986): Characterization of Yersinia enterocolitica and related species isolated from foods and porcine tonsils in the Netherlands. Int. J. Food Microbiol, 3:217:224.

Drake, R; John, I; Farrell, A; Cooper, W; Schuch, W. and Grierson, D. (1996): Isolation and analysis of cDNAs encoding tomato cysteine proteases expressed during leaf senescence. Plant Mol. Biol., 30(4):755-67.

Heesemann, J. and Grüter, L. (1987): Genetic evidences that outer membrane protein YOP1 of Yersinia enterocolitica mediates adherence and phagocytosis resistance to human epithelial cell. FEMS Microbiol. Lett., 40: 37-41.

Heesemann, J.; Keller, C.; Morawa, R.; Schmidt, N.; Siemens, H. J. and Laufs, R. (1983): Plasmids of human strains of Yersinia enterocolitica: Molecular relatedness and possible importance for pathogenesis. J. Infect. Dis., 147: 107-115.

Kapperud, G. (1991): Yersinia enterocolitica in food hygiene. Int. J. Food microbial., 12: 53-66

Kapperud, G.; Dommarsnes, K.; Skurnik, M. and Hornes, M. (1990): A synthetic oligonucleotide probe and a cloned polynucleotide probe based on the yopA gene for detection and enumeration of virulent Yersinia enterocolitica. Appl. Environ. Microbiol., 56:17-23.

Kapperud, G.; Namork, E.; Skurnik, M. and Nesbakken, T. (1987): Plasmid-mediated surface fibrillae of Yersinia pseudotuberculosis and Yersinia enterocolitica: relationship to the outer membrane protein YOP1 and possible importance for pathogenesis. Infect. Immun., 55: 2247-2254. Kapperud, G.; Vardund, T.; Skjerve, E.; Hornes, E. and Michaelsen, T. E. (1993): Detection of pathogenic Yersinia enterocolitica in foods and water by immunomagnetic separation, nested polymerase chain reactions, and colorimetric detection of amplified DNA. Appl. Environ. Microbiol., 59: 2938-2944.

Kwaga, J.; Iversen, J. O. and Misra, V. (1992): Detection of pathogenic Yersinia enterocolitica by polymerase chain reaction and Digoxigenin-labelled polynucleotide probes. J. Clin.Microbiol., 30: 2668-2673.

Lachica, R. V. and Zink, D. L. (1984): Determination of plasmid-associated hydrophobicity of Yersinia enterocolitica by a latex particle agglutination test. J. Clin. Microbiol., 19: 660-663.

Lee, W.H. (1977): Two plating media modified with tween 80 for isolating Yersinia enterocolitica. Appl. Environ. Microbiol., 33:215-216.

Millar, D.; Ford, J.; Sanderson, J.; Withey, S.; Tizard, M.; Doran, T. and Hermon-Taylor, J. (1996): IS900 PCR to detect Mycobacterium paratuberculosis in retail supplies of whole pasteurized cows' milk in England and Wales. Appl. Environ. Microbiol., 62: 3446-3452.

Mullis, K.B.; Ferre, F. and Gibbs, R.A. (1994): The polymerase chain reaction.Birkhauser, Boston.

Paerregaard, A.; Espersen, F.; Jensen, O. M. and Skurnik, M. (1991): Interaction between plasmids of human strains of Yersinia enterocolitica: Molecular relatedness and possible importance for pathogenesis. J. Infect. Dis., 147: 107-115.

Portnoy, D. A. and Martinez, R. J. (1985): Role of a plasmid in the pathogenicity of Yersinia species. Curr. Top. Microbiol. Immunol., 118: 29-51.

Ruckdeschel, K.; Roggenkamp, A.; Schubert, S. and Heesemann, J. (1996): Differential contribution of Yersinia enterocolitica virulence factors to evasion of microbicidal action of neutrophils. Infect. Immun., 64: 724-733.

Schiemann, D.A. and G. Wauters. (1992): Yersinia. P. 433-450. In Vanderzani, C. and Splittstoesser, D.E. (ed.), Compendium of methods for the microbiological examination of foods. Am. Pub. Health Assoc., Washington, D.C.

Skurnik, M. and Wolf-Watz, H. (1989): Analysis of the yopA gene encoding the Yop1 Virulence determinants of Yersinia spp. Mol. Microbiol., 3: 517-529.

Skurnik, M.; Böli, I.; Heikkinen, H.; Piha, S. and WolfWatz, H. (1984): Virulence plasmid associated autoagglutination in Yersinia spp. J. Bacteriol., 158: 10331036.

Swaminathan, B.; Haemon, M.C. and Mehlman, I.J. (1982): Yersinia enterocolitica. J. Appl. Bacteriol., 52: 151183.

Trkov, M.; Majerikova, I.; Jerasek, B.; Stefanovicova, A.; Rijpens, N. and Kuchta, T. (1999): Detection of salmonella in food over 30 hours using enrichment and polymerase chain reactions. Food Microbiol., 60: 393-399.

Ursing, J.; Berner, H.; Bercovier, G. R.; Fanning, A. G.; Syeigerwallt, J.; Brault and Mollaret, H. H. (1980): Yersinia ferderiksenii: a new species of Enterobacteriaceae composed of rhammnose-positive strain (formerly called atypical Yersinia or Yersinia enterocolitica like). Curr. Microbiol., 4:213-217.

Wren, B. T. and Tabaqchali, S. (1990): Detection of pathogenic Yersinia enterocolitica by the polymerase chain reaction. Lancet, 336: 693. 